\title{
The Principal Role as a Caregiver in Forming Students Character: A Study in Al-Izzah Secondary Boarding School Malang-East Java Indonesia
}

\author{
Muh Zainul Amin Nur*, Ali Imron, Imron Arifin \\ Department of Education, Faculty of Education Administration, Universitas Negeri Malang, Indonesia
}

Received January 24, 2020; Revised March 20, 2020; Accepted March 28, 2020

Copyright $\mathrm{C} 2020$ by authors, all rights reserved. Authors agree that this article remains permanently open access under the terms of the Creative Commons Attribution License 4.0 International License

\begin{abstract}
This study focuses on the principal role in Al-Izzah Secondary Boarding School Batu-Malang Est Java. This study found the fact concerning the uniqueness of the school, in which the school principal acts as a caregiver. An in-depth search has found that as a caregiver, a principal as someone, who does coaching and monitoring concerning the grade progress of students' character development in schools and dormitories, who report will be delivered later to parents. The principal made a number of efforts to support his role by living in an environment along with students, creating a clean and healthy environment in schools and dormitories, and making collaboration with students regarding tourist attractions for student tourism activities. Finally, he has to report the students' development concerning their core character values developed to parents. The results of this study provide information on the role of the principal as a caregiver and this character education is recommended to be applied at boarding schools and non-boarding schools.
\end{abstract}

Keywords Principal Role, Caregiver, Student Character, Boarding School

\section{Introduction}

Boarding school is a form of schooling that carries out education longer than regular school and full day school as it is arguably to have a 24-hour education. Boarding school is a school that provides a place to stay for students when they are studying and they will be allowed to return to their house on vacation (Kinney, 2017). A number of countries have already been familiar with this school model, for example in England it has come to practice around the 597s and in Canada it has existed around the 1788s(The British Tradition, 2018). Next, in America it was introduced around the 1700s (Bass, 2014), and followed by Australia around the 1880s (Jacobs, 2006) and finally Indonesia it came to public around 1718s known as Pesantren (Arifin and M Slamet, 2010). The system of this school model concerns with the effort in providing a good, stable, supportive learning environment which is able to protect, maintain, and facilitate students to do their best. In addition, this school model has also become a kind of solution for students having specificity (Behaghel, Chaisemartin and Gurgand, 2017). A school with this kind of system regulates student activities strictly starting from students regular scheduling from sleeping, waking up, studying, resting, schooling and doing worship (Arifin and M Slamet, 2010). Education in this school does not only focus on general academic ability, but it also focuses more on students' depth of religion and character. Therefore, the general vision and mission of the school cover three things, which are superior in academics, the depth of religious knowledge, and noble mind and good character (Abidin, 2013). Boarding school provides many advantages in their education; one of them is character education (Susiyani, 2017). This character education makes the community or students/ parents feel interested in to choose this school model for their children. Parents put their children into this school model as they expect that their children would learn characters such as discipline and leadership (Behaghel, Chaisemartin and Gurgand, 2017) furthermore, parents expect them to learn about good attitude and manner (Arifin and M Slamet, 2010).

The implementation of character education at schools has triggered school principals to play various roles (Ningsih and Zuchdi, 2015). According to Ajmain's research, the role of the school principal concerning students' character education lies on his role as a manager, a leader, a role model who encourages and supports the teamwork (Ajmain, 2016). In supporting character education, the school principal of Al-Izzah Secondary 
Boarding school has played a number of roles, one of which is acting as a caregiver. The role of a caregiver is usually performed by a kyai in the classical pesantren education environment. This is what makes the school principal of Al-Izzah unique. In carrying out the role of a caregiver, he chooses to live in the school environment with students and does technical work such as checking the students directly, monitoring students regularly, coordinating with staff, evaluating the development of students' character and reporting students' progress to parents formally. The behavior performed by Al-Izzah school principal is actually a form of adjustment to the school context. As Arifin explained, it is stated that effective school principals are school principals who are able to adjust himself to the needs and context of the school (Arifin, 2008).

Based on the explanation above, the researcher wants to explore the role of Al Izzah school principal as a caregiver by focusing on the discussion related to the activities of the school principal as a caregiver, the school principal efforts in supporting his role of a caregiver and the report the school sent to parents. The results of this study will provide information about the role of principals as a caregiver in secondary boarding schools.

\section{Method}

This research was conducted at the Al-Izzah school. Al-Izzah School is a Junior Secondary Boarding School specifically for fermale students. There are 540 students studying in this school and the students come from a number of regions or cities from various provinces in Indonesia. The method chosen in this research is qualitative. The choice of this method is triggered by the researcher's intention in carrying out a research in a natural situation by not changing the environmental settings and activities of the participants and interpreting a phenomenon that occurs by applying several data collection methods. This is in accordance to the opinion of Denzin and Lincoln who stated that qualitative study is a study with a natural setting, and intends to interpret a phenomenon that occurs by utilizing several methods (Denzin and Lincoln, 2009). The method used was interviews, observation and documents (Moleong, 2014). The use of semi-structured interviews was applied in this research. There were 41 informants in this research consisting of 1 principal, 4 vice principals, 8 teachers, 8 boarding caregivers, 20 students parents of grade 8 and 9 . The interview process was first carried out to the principal up to many times concerning the research theme being researched regarding the activities of the principal as a caregiver, the school principal's efforts in supporting his role of as a caregiver, and the report sent to students' parents. Furthermore, an in-depth research was carried out by conducting interviews with 4 vice principals, 8 teachers, 8 boarding caregivers, and 20 parents of students in grade 8 and 9 during a school visit. In order to explore the research themes that have been established as well as a triangulation of method regarding the data used, the researcher conducted field observations and study documents. Field observations carried out in this research were repeatedly carried out to obtain the situation or atmosphere and important events that occurred at school and in the dormitory associated with the research theme being researched, and research documents were also used to obtain official school information in the form of school documents which provide instructions or strengthen research themes that are being explored such as school principal job description documents, school programs, student report cards, and other. All data collected has been reduced, displayed, concluded and verified following the steps of Miles and Huberman (2014) in the process of data analysis namely data reduction, data presentation, and inference and verification. The explanation regarding those stages is as follows;

\subsection{Data Reduction}

Data reduction in study is done by sorting out relevant data and organizing in table columns based on study focus. The focus of this study covers (1) the principal's activities as a caregiver, (2) the school principal's efforts in supporting his role as mentor, and (3) reports of parenting to parents. Each focus has three columns, for filling in data obtained from interviews for the first column, observations for the second column and document data for the third column. And in each column space is provided to write notes, recommendations and short narratives.

\subsection{Data Display}

Data presentation in this study is presented in narrative form. To display data that has been reduced, the researcher made a pattern of relationships between phenomena with one another or data one with other data so that it is arranged into information that can be concluded and has a certain meaning.

\subsection{Conclusion Drawing and Verification}

Drawing conclusions in this study is one finding. The findings of this study are about the role of the principal as a caregiver in shaping the character of students in boarding schools. To get the conclusion, the researcher verified or matched the research data and clarification in the field.

\section{Findings}

This study found three main findings concerning the role of Al-Izzah school principal as a caregiver in shaping the character of students. They are (1) the principal's activities as a caregiver, (2) the efforts done in supporting the principal's role as a caregiver, (3) parents report 
regarding the students' development at school. Each of them is explained as follows:

\subsection{The Principal as a Caregiver}

Al-Izzah Secondary Boarding house school is a boarding school specifically for women. Al-Izzah Secondary School has the main mission of organizing good schooling, religious education, and character building. To carry out this vision, the school principle of Al-Izzah secondary School made a number of developments and adjustments in carrying out his roles and duties, one of which is as a caregiver. In the school document, it mentions the job description of Al-Izzah school principal as stated in point 13 stating "that the principal is responsible for aspects of care". As a caregiver, he is assigned to the following tasks namely (1) conducting coaching starting from student placement, arranging daily students' activities, determining the type of coaching, and determining students' companions in the dormitory, (2) conducting students' monitoring or monitoring students' daily activities in schools and dormitories related to the core values of character education developed by mobilizing the influential students, (3) making a report to parents every quarter of the year related to the eight core character of students developed by the school

\subsection{The Principal Efforts to Support his Role as a Caregiver}

In carrying out his role as the leader of Al-Izzah Secondary Islamic Boarding school, he did several things that were considered to support his role as a caregiver in shaping the character of students. The efforts are (1) living in the school or dormitory environment so that he can establish or communicate with students easily, (2) creating beautiful, clean, and green school and boarding environment by providing a place to socialize like gasebo. (3) having a cooperation with tourism objects around the school for student tourism. In this case, the school principal really makes use of the school location which is in the tourist area. The purpose of this collaboration is that the tourism object can serve as a place of entertainment for students who love doing outbound, riding horses, archery, swimming and others.

\subsection{Report to Parents}

The education organizer at Al Izzah Junior Secondary Boarding School periodically reports the progress of students' education to students. The report concerns on student's progress in terms of first the character education. Character education in Al-Izzah boarding school covers 8 core character values that are developed and reported to parents as nurturing activities. Those eight core values are
(1) courage and confidence, (2) self-control ability, (3) independence, (4) teamwork ability, (5) caring manner, (6) leadership (7) responsibility and trustworthy, and (8) honesty

\section{Discussion}

\subsection{The Principal as a Caregiver}

The implementation of boarding schools has a higher complexity of issues when compared to the implementation of regular schools or full-day schools because it requires the principal to be able to lead and manage the school well. According to Owens, leadership quality is the main means to achieve organizational goals. The principal as a leader in a school cannot only play one role, but he must play several roles. In accordance to Arifin's research regarding leadership of school principals in managing schools of authority, it is explained that the roles and tasks of school principals have undergone several developments in terms of roles, functions and tasks (Arifin, 2008). This is because they make adjustments in order to achieve goals. In fact, they play several roles at the same time. In line with the research results, Ningsih's school principals play various roles to support the implementation of character education in schools (Ningsih and Zuchdi, 2015). This is in accordance to the statement of the Al-Izzah school principal stating that the principal's duty here is not only as a school leader but also as a caregiver". The statement of the school principal was justified by the vive school principal in the field of care stating that the principal in this school also serves the head of caregivers". And in the school document about the job desription of the Al-Izzah school principal in point 13 is clearly stated "the principal is responsible for aspects of care". As a caregiver, what the Al Izzah school principal does is to provide guidance starting from the placement of students, arranging daily student activities, determining the type of coaching, and determining the student's assistant at the boarding school. The headmaster of Al-Izzah played a number of roles, one of which is becoming a caregiver in shaping the character of students. The head of Al Izzah Islamic School as a caregiver takes a number of actions, namely conducting coaching activities ranging from student placement, arranging daily student activities, determining the type of coaching, and determining student co-workers in the dormitory. Related to this, in the research of Ridhayanti, it is stated that the activities of caregivers in conducting coaching of students are carried out specifically and completely in terms of managing students (Ridhayanti, 2018). Activities to regulate these students include coaching, doing a placement, organizing activities and mentoring (Imron, 2012). Related to student assistance, the results of the analysis of the translation school documents include (1) 
monitoring children's psychological, social development, (2) disciplining children, (3) accustoming children to become religious children, that is obedient and obedient to religious teachings, (4) training self-management by regulating the needs of his own life, (5) training independence to complete the students assignments, (6) controling and regulating student activities, (7) providing input and directing students to be able to decide the solution for their own problems.

The next action taken is to monitor students' daily activities at school and in the dormitory regarding the discipline they perform, relationships between friends, personal problems, health, learning problems and others. This is consistent with the Arba's opinion stating that the caregiver's action is to educate, foster and maintain students to shape the behavior of students so that they will be better individuals who have noble characters (Arba, 2018). In this case, what is stated by Arba is in line with what the principal and vice-principal stated in the field of caring revealing trhe fact that the main orientation of care is for the formation of the character of students to be religious beings. The next action taken as a caregiver is to report the development of the character or personality of students to parents. Assessment is an important factor in education as it aims to measure the students' success and know the condition of education carried out (Arikunto and Yuliana, 2008). Assessment is a form of school responsibility to parents regulated in the Indonesian education system law stating that parents have the right to know the development of their children's education (DIKBUD, 2003)

\subsection{The School Principal Efforts to Support his Role as a Caregiver}

The school principal in supporting his role as a caregiver has made a number of efforts, one of which is living in a school boarding environment with students. Living in a student dormitory environment makes it easy for him to supervise and communicate with students. This is in line with the will of the Al-Izzah school principal who stated " when we are appointed as principals of our self-commitment we want to be closer to students so that communication is continuous, ... by living together with students we will know more about students, how to develop them, we can also monitor them, so when they have a problem we can help them quickly. This is identical with the role of the kyai in the Pesantren in caring for his students, where his residence is in the same neighborhood as the residence of students who are studying. According to a study of Qomar, it is stated that in the pesantren, the kyai house and boarding are in one complex, so that the kyai can have a well-built communication with his students easily (Qomar, 2015). Communication and interaction with good students is one form of efforts to instill character education (Purnadi, 2015). Structuring a green, clean, and healthy school and boarding environment and the provision of socializing facilities for students is the effort of the principal of Al Izzah Secondary Boarding School. This effort is intended to make the students feel comfortable and feel at home so they can follow the education process well. This is in line with the opinion of Konu and Rimpela stating that students will get comfort in school if they find their needs such as having good and social being, social relationships, clean environment, self-fulfillment, and health is well fulfilled and maintained (Konu and Rimpelä, 2002). Students who have received their comfort will be able to adapt, socialize, and manage themselves quickly by managing their personal needs such as eating and drinking, studying, and so on. The results of Yunawan's study explained that students who are comfortable will adapt faster than those who fell less comfortable, and students who can adapt themselves quickly (Yunawan, A.I, 2019).

Furthermore, the school principal also does cooperation with tourism objects around the school. In this case, the school principal really makes use of the school location which is in the tourist area. The purpose of this collaboration is that the tourism object can serve as a place of entertainment for students who love doing outbound, riding horses, archery, swimming and others. This collaboration is a work that students enjoy. Once a month, students with the school principal and teacher travel to places that have cooperated. This is important because students learn full every day, so the existence of this tour will help them nourish the mind, foster and increase their interest in learning (Widia et all, 2016)

\subsection{Report to Parents}

Schools serve as places for organizing education that are trusted by the community to educate students. Thus, they are obliged to report the development of the students to parents because parents are entitled to obtain information about the development of their children's education (Sudibyo et al., 2011). The information that parents are entitled to get from school is not only in the academic, non-academic aspects but also in the aspect of character. Character education is a deliberate effort to help learners so that they understand, pay attention and implement core values (Lickona. T, 2013). There are eight 8) core values developed at Al-Izzah Secondary Boarding School namely (1) courage and confidence, (2) self-control ability, (3) independence, (4) teamwork ability, (5) caring manner, (6) leadership (7) responsibility and trustworthy, and (8) honesty. The eight core values are explicitly stated in the formulation compiled by Puskur which ais extended into 18 character values namely religious, honest, tolerance, discipline, hard work, creative, independent, democratic, curiosity, national spirit, love of the motherland, respect for achievement friendly/ communicative, love peace, love to read, care about the environment, care about social, and responsibility (Puskur, 2010) 


\section{Conclusions}

In leading the boarding school, the school principal's role develops as he does not only play one role but plays several roles in order to support the implementation of character education. The role of caregiver is one of the roles played by the school principal at Al Izzah Boarding School. Acting as a caregiver, the school principle provides guidance, monitors, and assesses for the development of student character and reports it to parent. The efforts to support this role are by living in the school environment along with the students, creating a comfortable environment for students, and collaborating with tourist attractions in the local city for students' activities. Reporting the development of students' character to parents is one of the activities of the school principal regarding his role as a caregiver. The report contains the core character values developed by Al Izzah Boarding School.

\section{REFERENCES}

[1] Abidin (2013) 'Pedoman sekolah Al-Izzah International Islamic Boading School.', LPI Al Izzah. Batu Malang: LPI Al Izzah, p. 115.

[2] Ajmain (2016) Peran Guru dan Kepala Sekolah dalam Pendidikan Karakter Siswa di SMA Negeri 3 Yogyakarta. Universitas Negeri Yogyakarta.

[3] Arba, U. (2018) Peran Pengasuh dalam Membentuk Karakter Santi di LKS Anak PCA Dau Kabupaten Malang. Universitas Muhammadiyah Malang.

[4] Arifin, I. (2008) Kepemimpinan Kepala Sekolah dalam Mengelolah Sekolah Berprestasi. 2nd edn. Edited by S. Suryaningtyas. Yogyakarta: Adity Media Publishing.

[5] Arifin, I. and M Slamet (2010) Kepemimpinan Kyai Dalam Perubahan Manajemen Pondok Pesantren: Kasus Ponpes Tebuireng Jombang. 1st edn. Yogyakarta: Aditya Media.

[6] Arikunto, S. and Yuliana, L. (2008) Manajemen Pendidikan. 1st edn. Yogyakarta: Aditya Media.

[7] Bass, L. R. (2014) 'Boarding schools and capital benefits: Implications for urban school reform', Journal of Educational Research.

[8] Behaghel, L., Chaisemartin, C. de and Gurgand, M. (2017) 'Ready for boarding? The effects of a boarding school for disadvantaged students', American Economic Journal: Applied Economics.

[9] Denzin and Lincolen (2009) Hand Book of Qualitative Research. 1st edn. Yogyakarta: Pustaka Pelajar.

[10] DIKBUD (2003) UUSPN NO 20 TAHUN 2003. Indonesia.

[11] Imron, A. (2012) Manajemen Peserta Didik Berbasis Sekolah. 2nd edn. Jakarta: Bumi Askara.

[12] Jacobs, M. D. (2006) Indian Boarding Schools in
Comparative Perspective: The Removal of Indigenous Children in the United States and Australia, 1880-1940.

[13] Kinney, D. M. (2017) The Lived Experiences \& Sacrifices of African American \& Latino Males in the Boarding School Environment. University of Texas at Austin.

[14] Konu, A. and Rimpelä, M. (2002) 'Well-being in schools: A conceptual model', Health Promotion International. doi: 10.1093/heapro/17.1.79.

[15] Lickona.T (2013) Character Matters: Persoalan karakter, bagaimana membantu anak mengembangkan penilaian yang baik, integritas dan kebajikan penting lainnya. 2nd edn. Jakarta: Pt.Bumi Aksara.

[16] Moleong, L.. (2014) Metodologi Penelitian Kualitatif Edisi Revisi. Bandung: Remaja Rosdakarya.

[17] Ningsih, T. and Zuchdi, D. (2015) 'The Implementation of Character Education In 8 Th State Junior High School And 9 Th State Junior High School Purwokerto', Jurnal Pembangunan Pendidikan: Fondasi dan Aplikasi, 3(2), pp. 225-236.

[18] Purnadi, F. S. (2015) Pendidikan Karakter dalam Sekolah Berasrama.

[19] Puskur (2010) pengembanganpendidikan-budaya-dan-kara kter-bangsa.

[20] Qomar, M. (2015) Dimensi Manajemen Pendidikan Islam. Malang: Erlangga.

[21] Ridhayanti (2018) Peran Pengasuh dalam Pembinaan Kemandirian Anak Melalui Pendekatan Ajaran Islam. Universitas Islam Negeri Ar-Raniry.

[22] Sudibyo, L. et al. (2011) 'Peranan dan Dampak Teknologi Informasi dalam Dunia Pendidikan di Indonesia', Widyatama.

[23] Susiyani, A. S. (2017) 'Manajemen Boarding School dan Relevansinya dengan Tujuan Pendidikan Islam di Muhammadiyah Boarding School (MBS) Yogyakarta', Jurnal Pendidikan Madrasah, 2(2), p. 327.

[24] The British Tradition (2018) A Brief History of Boarding School_UK and Canada, Our KInds The Trusted Source.

[25] Widia et all (2016) Pengaruh Metode Karya Wisata Terhadap Hasil Belajar Siswa Tentang Ekonomi Masyarakat Sekitar.

[26] Yunawan, A.I (2019) Homesickness Pada Santri. Universitas Muhammadiyah Surakarta. 